\title{
SIMULASI PEMBANGKIT LISTRIK TENAGA SAMPAH DI STT PLN SEBAGAI BAGIAN DARI LISTRIK KERAKYATAN (LK)
}

\author{
RIZQIA CAHYANINGTYAS, ABDUL HARIS, ROSIDA NUR AZIZA, \\ LUQMAN, \& PUJI CATUR SISWIPRAPTINI \\ Program Studi Teknik Informatika STT-PLN Jakarta \\ Jl.Lingkar Luar, Duri, Kosambi, Cengkareng, Jakarta Barat 11750
}

\begin{abstract}
ABSTRAK
Listrik Kerakyatan adalah suatu gagasan untuk mengelola tenaga listrik dari sumber daya yang ada disekitar masyarakat, dengan menghimpun dan memanfaatkan berbagai teknologi sederhana dan murah yang cocok untuk dikelola oleh masyarakat awam. Bahan bakar utama dari Listrik Kerakyatan yang saat ini dikelola oleh STT PLN adalah Sampah perkotaan dan energi yang berasal dari Bio Massa. dan pengelolaan sampah ini pun sangat baik apabila dikembangkan baik diperkotaan, di daerah pedesaan serta daerah terpencil. Tentunya hal ini sangat relevan dengan kondisi Indonesia yang darurat penanggulangan sampah perkotaan, serta krisis energi listrik. Model listrik kerakyatan yang sudah dimatangkan ini masih memiliki kendala mengenai sosialisasi ke masyarakat luas, Salah satu masalah yang dihadapi adalah media untuk menjelaskan kepada masyarakat mengenai siklus atau arus pengubahan bahan sampah menjadi energi listrik. Model simulasi dianggap sebagai model yang sangat cocok untuk menyampaikan informasi yang dapat menjadi pengetahuan untuk masyarakat luas mengenai listrik kerakyatan. Tahapan pembuatan Simulasi Listrik Kerakyatan ini menggunakan metode Multimedia Development Life Cycle (MDLC) dimulai dengan konsep, rancangan, pengumpulan material bahan-bahan multimedia yang digunakan, pembuatan, pengujian sampai dengan distribusi. Dengan bahasa pemrograman VB.net dan $3 D$ Studio Max untuk membangun aplikasi simulasi.
\end{abstract}

Kata Kunci: Listrik Kerakyatan, PLN, PLTSA. VB.net, 3D Studio Max.

\section{PENDAHULUAN}

Sampah adalah permasalahan yang terjadi, tidak hanya di Indonesia, namun juga di seluruh dunia. Permasalahan sampah dan penanganannya telah menjadi perhatian khusus bagi dunia. Menurut Kementrian Lingkungan Hidup dan Kehutanan (KLKH) Indonesia adalah penghasil sampah plastik ke laut ke dua setelah Tiongkok (Wahyuni, 2016). Dirjen Pengelolan Sampah, Limbah, dan Bahan Beracun Berbahaya (PLSB3) KLHK, Tuti Hendrawati Mintarsih, menyebut total jumlah sampah Indonesia di 2019 akan mencapai 68 juta ton, dan sampah plastik diperkirakan akan mencapai 9,52 juta ton atau 14 persen dari total sampah yang ada. Target pengurangan timbunan sampah secara keseluruhan sampai dengan 2019 adalah 25 persen, sedangkan 75 persen penanganan sampahnya dilakukan dengan cara composting dan daur ulang. PLSB3 Kementerian Lingkungan Hidup dan Kehutanan juga menyatakan bahwa produksi sampah di Jakarta mencapai 70 ribu ton setiap hari dan sebanyak $60 \%$ dari sampah tersebut berasal dari sampah rumah tangga (Widyastuti, 2018). Oleh sebab itu dibutuhkan tindakan penanganan sampah yang tepat dan cepat untuk menindak lanjuti permasalahan sampah tersebut. Salah satu penanganan sampah yang dilakukan adalah dengan Daur ulang sampah menjadi bahan baku dan bahan jadi berupa produk yang dapat dimanfaatkan oleh masyarakat. Namun penggunaan produkproduk hasil limbah ternyata dapat mengakibatkan efek samping yang sangat berpengaruh buruk terhadap kesehatan manusia (Wilson et al, 2006 dan C.Ezeah et al, 2013) .

Banyak penelitian dilakukan untuk me- 
manfaatkan sampah menjadi sumber energi alternatif, salah satunya adalah dengan mengolah sampah tersebut menjadi biogas. Produksi biogas melalui pemrosesan anaerob telah dilakukan di banyak negara karena proses ini dipandang aman bagi lingkungan dan dapat diterapkan pada berbagai asal aliran sampah yang berbeda, misalnya sampah dari rumah tangga, limbah industri, dan sisa hasil pembangkitan listrik (Horvarth et al, 2016). Suatu riset di Cina Utara berusaha meneliti komposisi terbaik antara sampah makanan dan jerami (straw) pada proses fermentasi sampah yang memiliki potensi gas methane terbanyak (Yong,2015). Selain kombinasi sampah, riset untuk mengembangkan teknologi produksi biogas tersebut juga terus dilakukan, misalnya penelitian yang berkaitan dengan Anaerobic Membrane Reactor atau AnMBR (Visvanathan dan Abeynayaka, 2012; Wikandari et al.,2014). Peran masyarakat dalam pengolahan sampah juga menjadi bahan kajian, contohnya pada penelitian pengolahan sampah kota di Padang (Raharjo et.al, 2015) dan di Teheran (Ahmadi et al, 2013).

STT PLN sebagai Sekolah Tinggi di bidang teknik turut berpartisipasi untuk menangani permasalahan sampah sehingga sampah dapat diolah dan dimanfaatkan untuk kebutuhan orang banyak. Hasil pengolahan sampah untuk masyarakat harus "aman", yaitu memiliki tingkat polusi dan limbah yang rendah. STT PLN membuat Tempat Olah Sampah Setempat (TOSS) untuk mengolah sampah menjadi briket dan pelet melalui proses fermentasi, atau disebut peuyeumisasi. Hasil dari peuyeumisasi sampah tersebut dapat digunakan untuk kebutuhan masyarakat, seperti bahan bakar kompor, pupuk, pakan ternak, sampai dengan kebutuhan listrik tenaga uap.

Listrik Kerakyatan adalah suatu gagasan untuk mengelola tenaga listrik dari sumber daya yang ada di sekitar masyarakat saat ini dengan menghimpun dan memanfaatkan berbagai teknologi sederhana dan murah yang cocok untuk dikelola oleh masyarakat awam. Bahan bakar utama dari Listrik Kerakyatan ini adalah sampah perkotaan dan energi yang berasal dari bio massa. Tentunya hal ini sangat relevan dengan kondisi Indonesia yang darurat penanggulangan sampah perkotaan serta krisis energi listrik, terutama di daerah pedesaan serta daerah terpencil. Hasil penelitian dan uji coba yang dilakukan oleh STT PLN telah berhasil menanggulangi sampah sebanyak 1 ton per hari (organik dan/atau non organik), dikonversi menjadi briket sampah sebagai bahan bakar pembangkit listrik gas sampah melalui proses gasifikasi. Terkait briket sampah ini, penelitian yang dilakukan oleh STT PLN di Laboraturium Pengujian Pusat Penelitian dan Pengembangan teknologi Mineral dan Batu Bara (TekMIRA) Kementerian ESDM pada 24 Juni 2015 membuktikan bahwa kadar kalori briket sampah ini berkisar antara 2500 kkal (kalori rendah), 4.445 kkal (kalori sedang), dan 6.730 kkal (kalori tinggi). Dalam hal ini, briket sampah ini mampu menjadi energi baru dan mampu menggantikan energi batu bara. Namun untuk dapat diimplementasikan dalam skala nasional, dibutuhkan penelitian lanjutan dengan ruang lingkup yang lebih luas, baik dari sisi teknis dan non teknis.

Model pembangkitan listrik yang sedang dikembangkan ini masih memiliki kendala, terutama sosialisasi ke masyarakat luas tentang adanya model penyaluran listrik ini. Salah satu masalah yang dihadapi adalah media untuk menjelaskan kepada masyarakat mengenai siklus atau arus (proses) pengubahan bahan sampah menjadi energi listrik. Model simulasi dianggap sebagai model yang sangat cocok untuk menyampaikan informasi mengenai listrik kerakyatan kepada masyarakat luas mengenai listrik kerakyatan. Model simulasi adalah suatu proses peniruan dari sesuatu yang nyata beserta keadaan sekelilingnya (state of affairs).

\section{PLTSA (PEMBANGKIT LISTRIK TENAGA SAMPAH)}

Secara teknik sudah banyak kelompok masyarakat yang berinisiatif untuk mengelola sampah dimulai dengan memisahkan sampah organik. Pemanfaatannya pun beragam, mulai dari pupuk kompos, kerajinan tangan, biji plastik, sampah gas untuk masak. Secara regulasi, PLTSampah sudah didukung dengan adanya Feed in Tariff tetapi baru dimanfaatkan oleh pemodal besar karena perizinan dan prosedurnya sangat rumit dan berjenjang sampai ke tingkat menteri. Untuk itu prosedur IPP Kerakyatan yang menggunakan PLTSa perlu disederhanakan dan didelegasikan kepada unit 
PLN di tingkat cabang sehingga memudahkan pembuatan kontrak jual beli dengan PLN. PLTSa juga tidak terkendala oleh masalah pengadaan lahan karena lahan yang diperlukan per paket relatif kecil dan bersifat swadaya di tingkat kelurahan.

Model PLTSampah yang saat ini sedang dikembangkan adalah sampah organik. PLTSa organik juga relatif sederhana dan sudah banyak yang memanfaatkannya sebagai pengganti gas elpiji, dapat dikonvensi menjadi listrik dengan menggunakan genset yang khusus untuk gas methane. Keuntungan utama dari PLTSa adalah selalu tersedianya sampah organik selama masih ada manusia (setiap orang rata-rata menghasilkan sampah sekitar $0.76 \mathrm{~kg}$ per hari). Selain itu, PLTSa relatif sederhana dan sudah banyak yang memanfaatkannya sebagai pengganti gas elpiji, tinggal dikonversi menjadi listrik dengan menggunakan genset yang khusus untuk gas methane. Dari sisi lingkungan, PLTSa bisa memberikan solusi atas masalah pembuangan sampah dan limbah akhir sampah berupa pupuk memiliki nilai ekonomis (Legino, 2016).

Ide dari Listrik Kerakyatan (LK) berawal dari upaya pengelolaan untuk kemudian memanfaatkan sampah rumah tangga di RW 10 Kelurahan Pondok Kopi, Jakarta Timur untuk dijadikan dijadikan lindi cair dan kompos. Penelitian yang diprakarsai oleh warga dengan STT PLN diawali dengan menguji bio digester yang dikembangkan oleh peneliti dari Universitas Padjadjaran, Bapak Fatah. Konsep dasar dari bio digester ini adalah proses fermentasi $100 \%$ sampah organik dengan menggunakan bakteri anaerob (jenis bakteri yang tidak memerlukan udara/oksigen) dengan tujuan untuk menguraikan sampah tersebut sehingga menghasilkan gas metan dan pupuk cair (lindi). Gas metan $\left(\mathrm{CH}_{4}\right)$ dapat dimanfaatkan sebagai bahan bakar, sedangkan lindi dapat dimanfaatkan sebagai pupuk dan campuran makanan ternak. Penelitian ini telah berlangsung selama 4 tahun hingga akhirnya mendapatkan model yang tepat dan hasil dari biogás dan pupuk dapat dimanfaatkan oleh pengelola LK Pondok Kopi dan masyarakat setempat.

Model Bio Digester di RW 10, Kelurahan Pondok Kopi, Jakarta Timur tersebut baru bisa mengelola sampah organik yang jumlahnya tidak lebih dari 20 persen sampah yang ada, sehingga perlu dilakukan penelitian berikutnya untuk mengolah sampah secara tuntas yang disebut kondisi "Zero Waste". Selain itu, gas metan yang dihasilkan dari proses biodigestasi tidak ramah lingkungan dan memiliki daya ledak yang cukup tinggi jika disimpan dalam volume yang besar. Proses biodigestasi tersebut memanfaatkan bakteri yang mirip dengan bakteri dalam pembuatan tape (peuyeum, dalam bahasa Sunda) sehingga kita sebut sebagai "Peuyeumisasi". Metode yang merupakan proses fermentasi alami tersebut menggunakan bak bambu terbuka dan hasil pemrosesannya mampu menghilangkan bau sampah dan mengurangi volume sampah secara alami. Kondisi Zero Waste bisa dicapai karena seluruh sampah dapat dirubah menjadi briket, yang dapat digunakan sebagai bahan bakar gas pembangkit tenaga listrik melalui proses gasifikasi. Untuk sampah non organik lain yang memiliki nilai jual seperti kaleng, botol kaca, dan plastik sudah diambil lebih dahulu untuk dijual, sedangkan serpihan kantong-kantong plastik sedang dalam proses penelitian untuk diolah menjadi "dodol plastik" sebagai penambah kalori proses peyeumisasi.

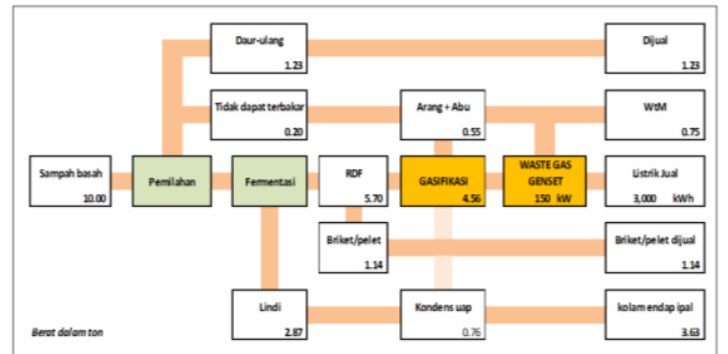

Gambar 1. Dasar perhitungan kesetaraan material dalam alur pemrosesan 10 ton per hari

Blok diagram pada Gb.1 menunjukkan kesetaraan material dan alur pemrosesan sampah dengan kapasitas 10 ton per hari. Pada setiap TOSS dengan kapasitas 10 ton tersebut, , terdapat beberapa parameter yang bisa dihitung sebagai berikut: 
1

Masukan dan Proses

1. Kapasitas pengolahan

2. Kebutuhan air olah balik

3. Total masukan

2. Keluaran dari Proses Olah Sampah Basah
1. Berat organik basah \& bahan terbakar

(RDF)

2. Berat bahan daur-ulang

3. Berat bahan tidak terbak

4. Berat lindi dan air balik

3. Hasil Produksi Akhir

1. Listrik

2. Briket bahan bakar sisa

3. Daur ulang

4. Bahan bangunan

5. Air bersih,

Kapasitas Olah Sampah Dan Kebutuhan Lahan

Rencana Kapasitas

Lama simpan proses (waktu siklus)

Bentukan simpan sampah

Ukuran keranjang

Volume (berat) keranjang

Formasi kernjang

Banyak gunungan

Kebutuhan lahan keranjan

Kebutuhan IPAB dan IPAL

0. Total lahan olah sampah basah

Kebutuhan Luas Bangunan dan Pekerjaan Sipi

(Standar kualitas dari kementrian terkait, Pemukiman-Prasarana dan Lingkungan-Hidup)
1. Luas lahan beratap olah sampah basah
$: 180 \mathrm{~m}^{2}$
2. Luas lahan beratap pembuatan briket/blok
: $200 \mathrm{~m}^{2}$
3. Luas bangunan pendukung (penuh)
: $380 \mathrm{~m}^{2}$
4. Kolam air kotor dan air bersih
$20 \mathrm{~m}^{2}$

Setiap 1 (satu) $\mathrm{kg}$ briket sampah atau biomass tanaman biasa seperti serpih kayu keras (15\%-kadar-air) yang akan digunakan sebagai bahan bakar gasifier akan menghasilkan $2,185 \mathrm{~m}^{3}$ gas-biomass atau $0,75 \mathrm{kWh}$ listrik atau $\sim 10.000$ BTU. Nilai kalori briket dari fermen ini lebh baik dari kayu bakar keras (yaitu sekitar $2.500 \mathrm{kal} / \mathrm{gram}$ ), dimana pada umumnya briket fermen untuk pembangkitan memiliki nilai kalor antara 2.500 $3.500 \mathrm{kal} / \mathrm{gram}$. Dengan asumsi kayu bakara keras saja maka untuk:
1. Pembangkitan $150 \mathrm{~kW}$
: 0,75 ton/jam
2. Untuk produksi listrik efektif jual
3. Konversi briket menjadi gas
: $3.000 \mathrm{kWh}$ per hari $(24 \mathrm{jam})$
4. Kebutuhan briket
: Gasifikasi
: 4,56 ton per hari
5. Sisa briket untuk kebutuhan lain
1,14 ton per hari

\section{METODE PENELITIAN}

\section{Tahapan Penelitian}

Tahapan-tahapan penelitian yang digunakan dalam pembuatan simulasi listrik kerakyatan ini adalah dengan menggunakan metode MLDC (Multimedia Life Development Cycle). Pada tahap analisis dan perancangan sistem untuk aplikasi simulasi Listrik Kerakyatan ini akan menggunakan metode pengembangan Multimedia yang dikenal dengan istilah Multimedia Development Life Cycle (MLDC). Adapun tahap-tahap dalam
MDLC adalah seperti berikut: penentuan konsep, pembuatan rancangan, pengumpulan materi (material collecting), penggabungan materi yang didapat (assembly), pengujian, dan distribusi.

\section{Analisis Penelitian (Concept)}

Aplikasi ini akan dibuat dengan tujuan untuk kegiatan sosialisasi dan manajemen sampah menjadi listrik. Aplikasi akan dibuat dengan Visual Studio. Sebagai outputnya akan didapat sebuah aplikasi desktop yang terdiri dari media foto, video interaktif, simulasi dan suara.

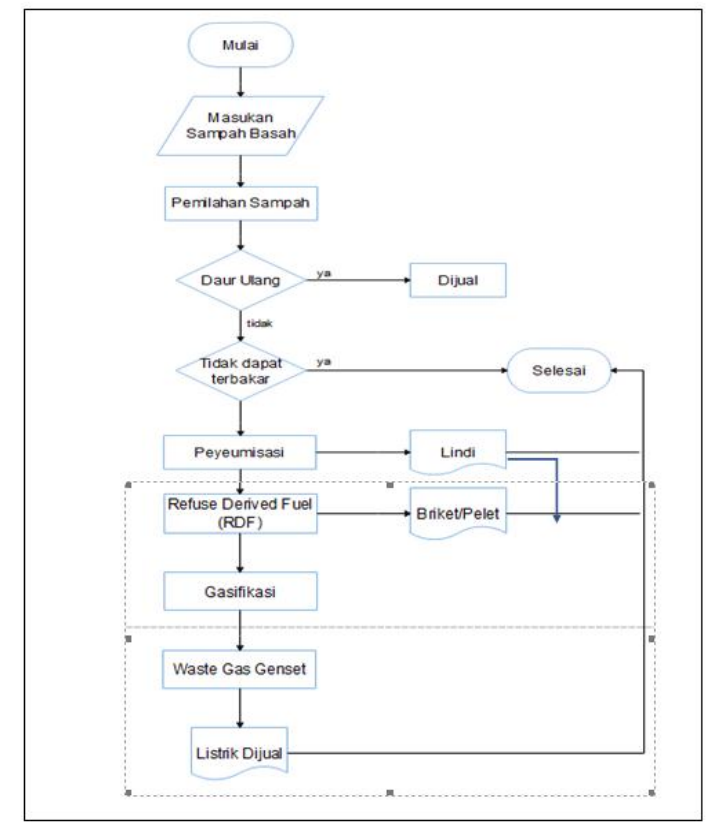

Gambar 2. Diagram Alir Sistem Berjalan pada LK

\section{1) Analisis Sistem Berjalan}

Gambar 2 menunjukkan diagram alir sistem yang sedang berjalan di Listrik Kerakyatan saat ini. Pada gambar tersebut, terdapat beberapa istilah yang tidak umum. Berikut adalah penjelasan mengenai istilah-istilah dari gambar 2:

a. Peyeumisasi

Sampah oganik kering, plastik dan lainnya dimasukan kedalam keranjang bambu proses inilah yang disebut dengan peyeumisasi yang berfungsi untuk mengecilkan volume dan menurunkan kadar air pada sampah organik kering selama seminggu atau 7 hari. Proses ini harus dicampurkan dengan lindi yang berasal dari digester sebagai pengganti garan. Setelah 7 hari hasil peyeumisasi dimasukan ke dalam pencacah/ crusher. Lalu serbuk hasil pencacahan akan dibentuk de- 
ngan mesin pembentuk agar dapat menjadi briket/pelet.

\section{b. RDF (Refuse Derived Fuel)}

RDF adalah proses peningkatan nilai kalori sampah, baik sampah biodegradable atau non-biodegradable dengan cara biomekanis (BM), terutama untuk menurunkan kadar air sampah dan mengurangi emisi gas berbahaya bagi lingkungan.

\section{c. Gasifikasi}

Gasifikasi merupakan suatu mekanisme untuk memproses pelet dan briket. Pelet dan briket akan dimasukan kedalam suatu reaktor kemudian dipanaskan pada temperature 500$1200^{\circ} \mathrm{C}$ sehingga susunan senyawa $\mathrm{C}_{6} \mathrm{H}_{10} \mathrm{O}_{5}$ berubah menjadi $\mathrm{CO}, \mathrm{H}_{2}$, dan $\mathrm{CH}_{4}$. Pelet dan briket inilah yang nanti akan berfungsi sebagai gas pembakaran yang panasnya akan digunakan sebagai listrik.

d. Lindi

Lindi adalah hasil dari proses digestasi. Digestasi adalah proses pengolahan sampah rumah bekas makanan di masukan kedalam biodigester diolah untuk menjadi gas metan dan cairan lindi.

Berikut adalah penjelasan pengolahan sampah menjadi listrik pada listrik kerakyatan:

1. Sampah organik dan non-organik mulai dipisah dengan menyediakan ember untuk organik.

2. Sampah organik dikumpulkan dan dimasukan oleh petugas ke dalam digester yang berada pada lumbung LK

3. Apabila ada sampah organik yang berupa dedaunan segar dicacah dan dicampur dengan lidi agar bias menjadi kompos agar bias ditambhakan ke digester.

4. Sampah non-organik yang masih berharga seperti plastik bekas minuman dikumpulkan untuk dijual kepada pengepul

5. Sampah non oganik berupa plastic dan karton atau kayu-kayuan yang rusak dan sisa-sisa sampah lainnya dihancurkan dengan cara dibakar dengan menggunakan tungku "Sidaus". Panas yang terbentuk akan dikumpulkan dalam biogas storage yang akan di alirkan ke genset yang selanjutnya menjadi daya listrik yang bermanfaat bagi masyarakat.

Selain pemaparan tentang skema proses yang berjalan di Listrik Kerakyatan, penulis juga akan maparkan beberapa kelemahan yang akan dijelaskan pada tabel 3.1 Tabel Evaluasi Sistem Saat ini:

Tabel 1. Kelemahan Sistem Saat ini

\begin{tabular}{|c|l|}
\hline No & \multicolumn{1}{|c|}{ Kelemahan Sistem Saat Ini } \\
\hline 1 & $\begin{array}{l}\text { Kurangnya suatu media yang menarik untuk } \\
\text { mengedukasi masyarakat mengenai pengolah } \\
\text { listrik menjadi sampah }\end{array}$ \\
\hline 2 & $\begin{array}{l}\text { Kurang maksimalnya fungsi pengawasan dan } \\
\text { keberlanjutan program listrik kerakyatan }\end{array}$ \\
\hline 3 & $\begin{array}{l}\text { Belum terdapat sistem pendataan (database) } \\
\text { secara terkomputerisasi mengenai pengolahan } \\
\text { sampah harian dan produksi listrik }\end{array}$ \\
\hline
\end{tabular}

\section{2) Analisis Sistem Usulan}

Dari hasil evaluasi sistem yang sedang ada saat ini dan adanya kelemahan-kelemahan pada sistem yang dijelaskan dari tabel 3.1 maka penulis mengusulkan untuk membuat suatu aplikasi simulasi listrik kerakyatan yang dapat dijadikan sebagai media pembelajaran dan sosialisasi yang dapat digunakan oleh tim yang bertanggungjawab atas proyek listrik kerakyatan.

Aplikasi simulasi ini akan dibuat dengan mengumpulkan beberapa objek yakni objek foto, video animasi dan suara dengan menggunakan Visual Studio 2008. Aplikasi simulasi ini dibuat dengan tampilan 2D yang diantaranya adalah:

1. Penjelasan tentang proses PLTSa melalui media suara;

2. Video animasi penjelasan proses pada PLTSa;

3. Simulasi perhitungan PLTSa;

4. Pengolahan data pengujian PLTSa; dan

5. Hasil peramalan produksi listrik PLTSa dengan metode moving average.

Simulasi yang dirancang akan menampilkan informasi mengenai proses pengolahan sampah menjadi listrik. Selanjutnya data tersebut akan ditambahkan dengan mediamedia interaktif lainnya seperti foto, video dan suara yang akan membuat tampilannya menjadi lebih menarik. Alur dari aplikasi ditunjukkan pada gambar 2. Selain berisi proses pengolahan sampah menjadi listrik, aplikasi simulasi ini juga dilengkapi dengan analisis peramalan dengan metode moving average yang dapat meramalkan proses terbentuknya sampah. Selain itu, hasil ramalan juga dapat disimpan dan dicetak dalam format .pdf sehingga memudahkan untuk proses pelaporan dan pengujian proses pengolahan sampah. 


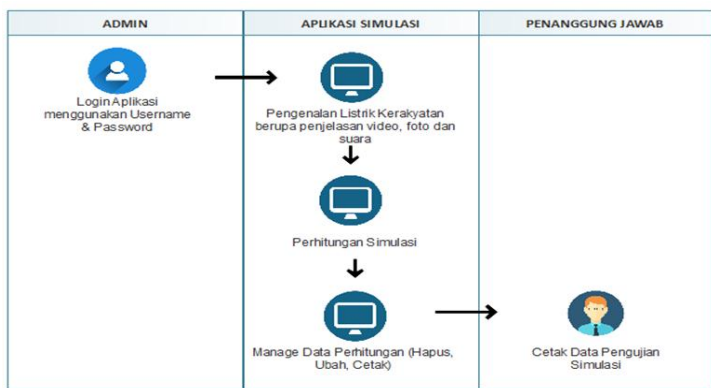

Gambar 3. Diagram Aplikasi yang Diusulkan

3) Analisis Input Output Proses

Analisis Fungsional adalah analisis yang berisikan input, output dan proses yang ada pada aplikasi. Berikut adalah analisis fungsional dari aplikasi simulasi listrik kerakyatan:

Tabel 2. Tabel Analisis Input Proses Output

\begin{tabular}{|c|l|l|}
\hline INPUT & \multicolumn{1}{|c|}{ PROSES } & \multicolumn{1}{c|}{ OUTPUT } \\
\hline $\begin{array}{c}\text { Berat } \\
\text { Sampah } \\
\text { TTON] }\end{array}$ & $\begin{array}{l}\text { 1. Masukan } \\
\text { Berat Sampah }\end{array}$ & $\begin{array}{l}\text { 1. Hasil Perhitungan } \\
\text { Sampah Organik }\end{array}$ \\
\hline & $\begin{array}{l}\text { 2. Tekan button } \\
\text { input }\end{array}$ & 2. Lindi [TON] \\
\hline & & 3. Air Balik [LITER] \\
\hline & & 4. Briket [TON] \\
\hline & & 5. Abu Sisa [TON] \\
\hline & & 6. Listrik [Kwh] \\
\hline
\end{tabular}

4) Analisis Kebutuhan Perangkat Lunak

Adapun kebutuhan perangkat lunak untuk membuat aplikasi ini adalah:

Tabel 3. Analisis Kebutuhan Perangkat Lunak

\begin{tabular}{|c|c|c|c|}
\hline No. & $\begin{array}{c}\text { Jenis } \\
\text { Software }\end{array}$ & $\begin{array}{l}\text { Spesifikasi Minimum } \\
\text { Perangkat Lunak }\end{array}$ & $\begin{array}{c}\text { Spesifikasi } \\
\text { Perangkat yang } \\
\text { Digunakan } \\
\end{array}$ \\
\hline 1. & $\begin{array}{l}\text { Operating } \\
\text { System }\end{array}$ & Windows XP & $\begin{array}{l}\text { Windows 7, } 64 \\
\text { Bit }\end{array}$ \\
\hline 2. & $\begin{array}{l}\text { Software } \\
\text { Aplikasi }\end{array}$ & $\begin{array}{l}\text { Microsoft Visual } \\
\text { Studio, SQL Server } \\
\text { Management Studio } \\
\text { Ekspress }\end{array}$ & $\begin{array}{l}\text { SQL Server } \\
\text { 2005, Microsoft } \\
\text { Visual Studio } \\
2008 \\
\end{array}$ \\
\hline 3. & Editing & Adobe Audition & Adobe Audition \\
\hline
\end{tabular}

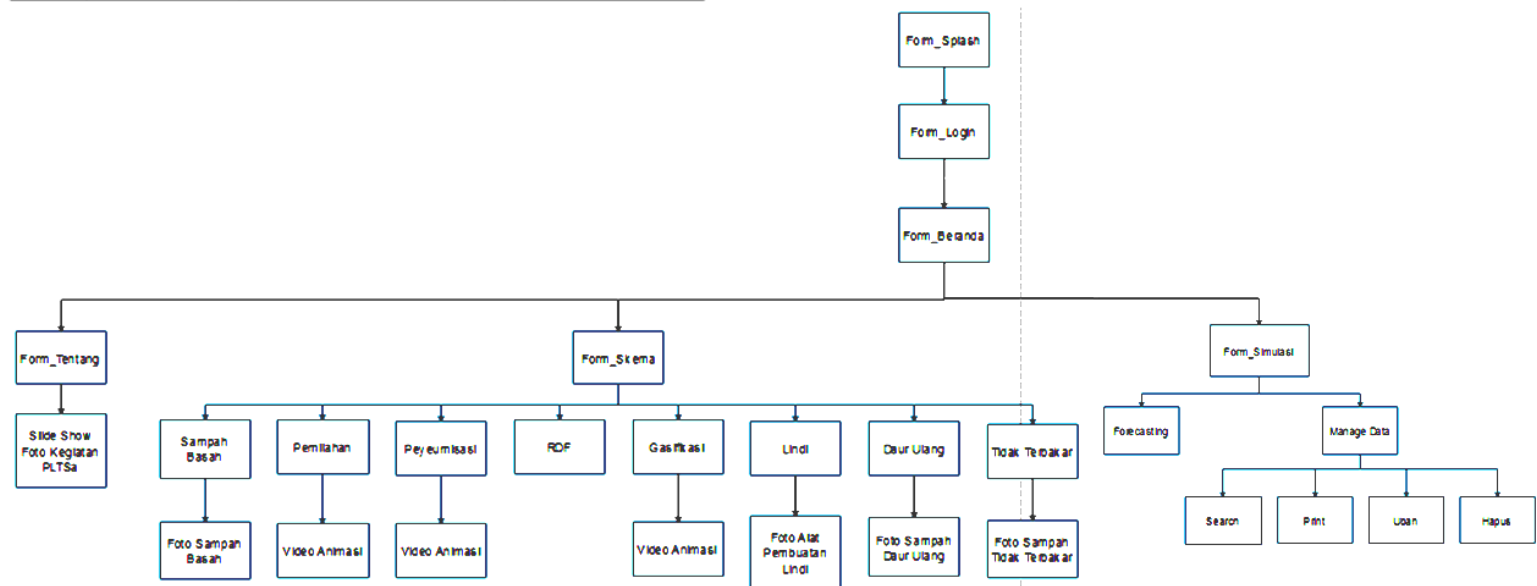

Gambar 4. Perancangan Menu Hirarki
Untuk brainware, simulasi ini diharapkan dapat digunakan oleh petugas Listrik Kerakyatan dan instansi yang berkaitan dengan listrik seperti PT. PLN Persero untuk dapat mengedukasi masyarakat luas mengenai LK dan mendorong minat masyarakat untuk secara bergotong royong menyediakan listrik untuk kebutuhannya. Selain itu aplikasi itu juga diharapkan dapat membantu petugas LK untuk melakukan rekap data pengujian LK dan melaporkannya kepada penanggungjawab.

\section{Perancangan Penelitian (Design)}

Tahap design adalah tahapan perancangan pada pembuatan aplikasi multimedia. Pada penulisan ini penulis membagi tahapan perancangan menjadi 4 yakni perancangan struktur menu hirarki, perancangan sistem, perancangan antar muka dan perancangan basis data.

1) Flowchart Rancangan Sistem

Aplikasi ini akan digunakan oleh admin untuk mensosialisasikan kegiatan listrik kerakyatan. selain itu admin juga dapat melakukan pengujian data terkait proses pro-duksi listrik kerakyatan yang hasil ujinya dapat di cetak dan diserahkan oleh penangggungjawab LK sebagai bahan laporan harian pelaksaan. 


\section{2) Perancangan Struktur Hirarki Menu}

Perancangan struktur hirarki menu (seperti pada Gambar 4) dibuat untuk mempermudah dalam dalam pembuatan aplikasi Simulasi Listrik Kerakyatan ini. Perancangan menu hirarki ini dimulai dengan tampilan splash tampilan splash ini adalah tampilan pembuka sebelum masuk ke menu login. Setelah adanya tampilan pembuka ini maka user akan masuk ke tampilan login dimana user harus memasukan username dan password untuk masuk ke tampilan home. Pada tampilan home terdapat skema proses listrik kerakyatan. Diform ini terdapat beberapa buttton aktif yang akan menampilkan video animasi untuk sampah basah, pemilahan dan peyeumisasi. Selain itu terdapat satu button yang akan menampilkan menu simulasi yang akan membuat proses sampah menjadi listrik dan juga dapat me-manage data yang telah diujikan atau disimulasikan.

\section{3) Perancangan STD (State Transition Dia- gram)}

Pada perancangan sistem ini, sistem akan dirancang untuk mengurangi permasalahan yang ada pada proses mencari hasil akhir suatu permasalahan. Pada perancangan proses ini penulis akan membuat dalam bentuk STD (State Transition Diagram). Perancangan STD (State Transistion Diagram) dibuat untuk menggambarkan state yang satu dihubungkan dengan state yang lainnya.

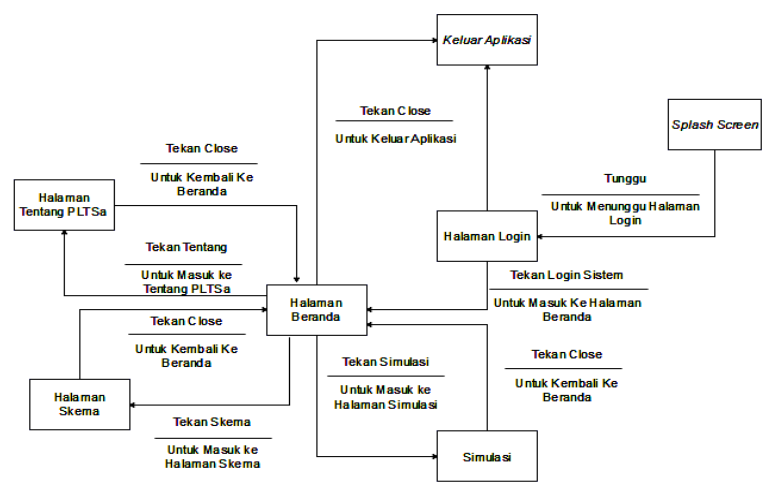

Gambar 5. Perancangan Utama STD

Gambar 5. menjelaskan perancangan utama STD dari tampilan simulasi listrik kerakyatan. Gambar 5. menjelaskan alur transisi dari tampilann splash sampai ke halaman beranda dan memilih pilihan tentan PLTSa, simulasi dan skema PLTSa.

Halaman splash menampilkan tampilan splash yang terdapat progress bar untuk menunggu masuk ke laman login. Setalah progress bar selesai maka aplikasi akan masuk ke tampilan login. Transisi setelah tampilan splash adalah tampilan login. Tampilan login akan muncul setelah progress bar dari tampilan splash selesai. Setelah itu klik button login maka tampilan akan berpindah ke tampilan home.Namun perancangan STD pada gambar 3.5 belum menjelaskan sub transisi di beberapa menu. Berikut adalah perancangan STD lebih lanjut dari beberapa pilihan menu pada gambar 3.5

\section{a. STD Halaman Skema PLTSa}

Halaman Skema PLTSa akan memuat video dan foto dari proses pengolahan sampah menjadi listrik. Berikut adalah perancanga STD dari Halaman Skema PLTSa/ Gambar 6 menjelaskan mengenai proses transisi yang terjadi di halaman skema. Pada halaman skema terdapat beberapa button aktif untuk melihat video yakni button di skema gasifikasi, pemilahan dan peyeumisasi. Ketiga button tersebut apabila di klik akan menampilkan video animasi yang berbeda dari masing-masing button yang di tekan.

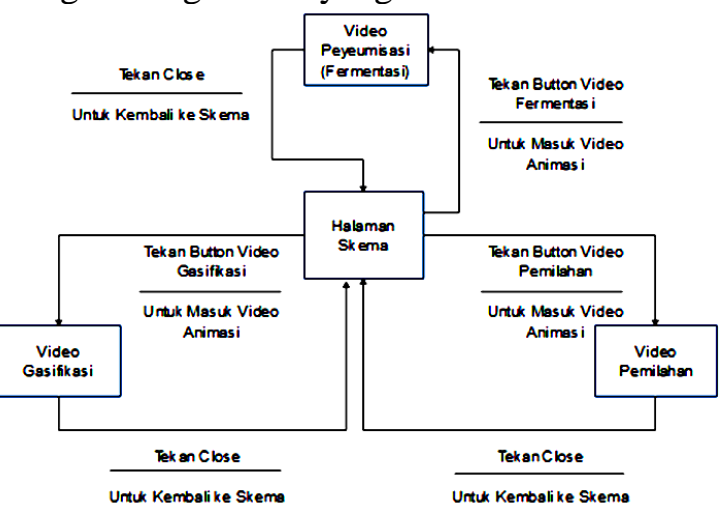

Gambar 6. STD Halaman Skema PLTSa

b. STD Halaman Simulasi

Halaman Simulasi adalah halaman yang memuat perhitungan simulasi dan hasil peramalan simulasi dengan metode moving average. Berikut adalah perancangan STD dari halaman simulasi. 


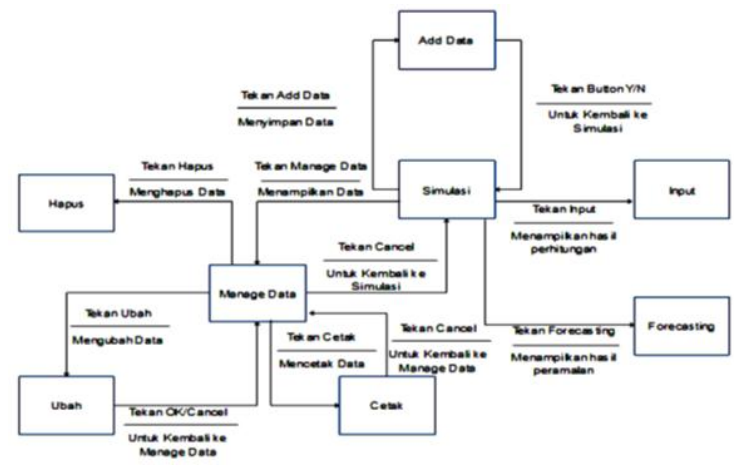

Gambar 7. STD Halaman Simulasi

Pada halaman simulasi terdapat button input untuk memasukan banyak sampah yang akan disimulasikan dan ada button-button untuk mengelolah data yang disimulasikan. Selain itu juga terdapat button forecasting untuk melihat hasil peramalan berdasarkan data yang pernah di simpan.

\section{HASIL DAN PEMBAHASAN}

Hasil dari perancangan aplikasi simulasi listrik kerakyatan yang diimplementasikan melalui aplikasi Visual Studio adalah sebagai berikut:

\section{Skema PLTSa}

Gambar 8. adalah Skema PLTSa pada skema ini terdapat beberapa button aktif untuk menampilkan foto dan video animasi proses pengolah sampah pada PLTSa.

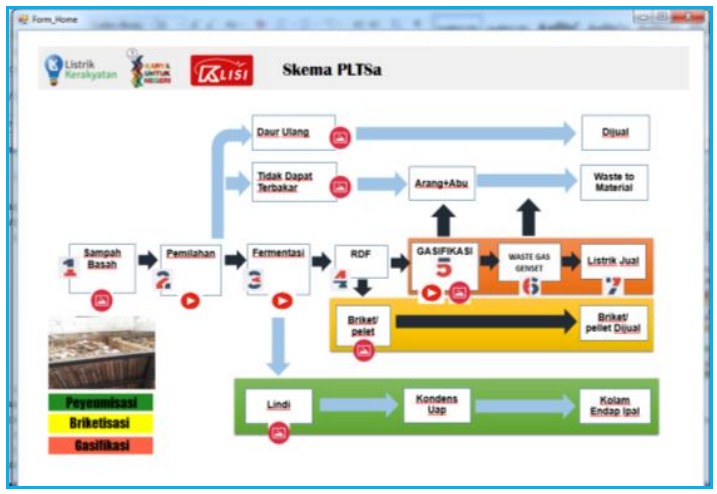

Gambar 8. Skema PLTSa

\section{Simulasi PLTSa}

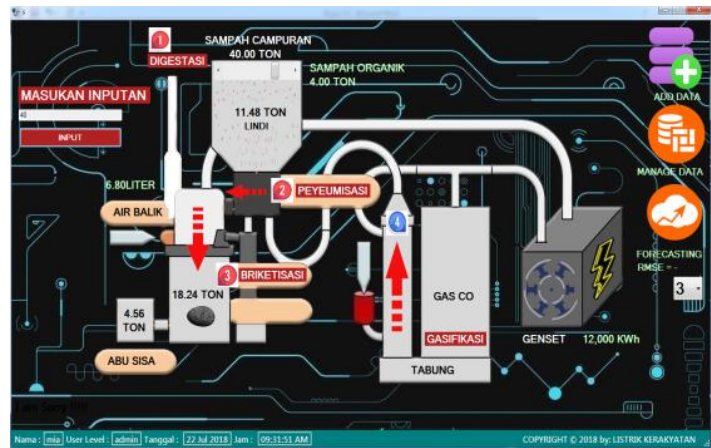

Gambar 9. Simulasi PLTSa

Gambar 9. adalah gambar tampilan pilihan menu Simulasi PLTSa. Menu ini merupakan menu utama untuk mensimulasikan proses perhitungan pengolahan sampah menjadi listrik. Pada menu ini terdapat button input yang akan menggerakan hasil perhitungan untuk masing-masing tahapan yang ada di LK. Tahapan-tahapan yang ada diantaranya adalah tahap digestasi, tahap peyeumisasi, tahap briketisasi dan tahap gasifikasi. Masing-masing tahapan apabila di tekan akan memunculkan komponen suara berupa penjelasan dari masing-masing tahapan tersebut. Selain itu juga terdapat fitur mouseHover dan mouseLeave dimana apabila mouse didekatkan akan menampilkan foto-foto alat dan keterangan dari proses LK.

\section{1) Add Data}

Data yang telah di ujikan dalam simulasi dapat disimpan berdasarkan tanggal dan waktu pensimulasianya dengan menambahkan data yakni menekan image button Add Data.

SIMPAN DATA
Simpan Data?
Tanggal : $7 / 14 / 2018$
Sampah Campuran sebanyak 18.19 TON

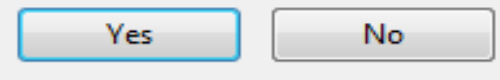

Gambar 10. Message Dialog Add Data

\section{2) Manage Data}

Setelah ditambahkan, data-data akan disimpan. Untuk melihat data-data yang pernah diujikan sebagai masukan sampah dan disimulasikan, pengguna dapat menekan image button manage data. 


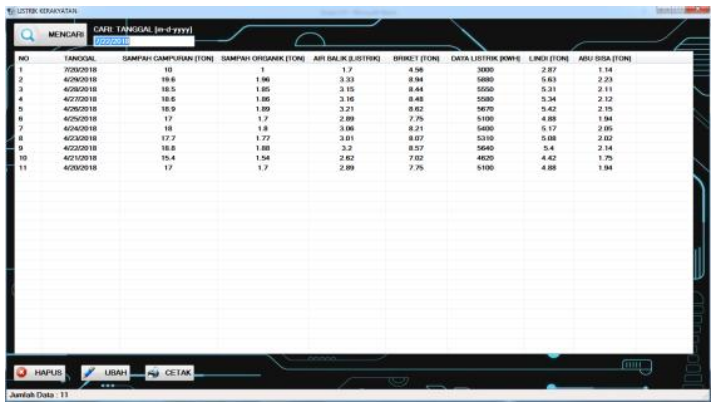

Gambar 11. Manage Data

Gambar 11 adalah tampilan manage data. Data yang telah disimpan dapat dihapus diubah dan dicetak.

\section{3) Cetak Data}

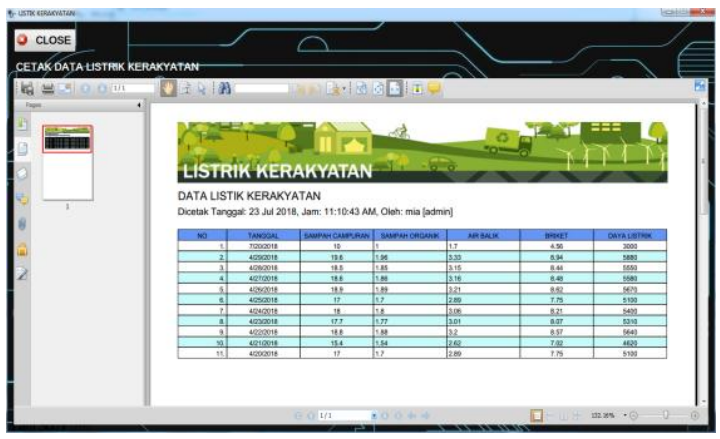

Gambar 12.Cetak Data

Data yang telah diujikan dapat dicetak dalam bentuk .pdf untuk dapat dilaporkan pada penanggung-jawab LK sebagai laporan harian pengujian pengolahan sampah menjadi listrik.

\section{KESIMPULAN}

Dari perancangan dan pembuatan simulasi Pembangkit Listrik Tenaga Sampah (PLTSa) dapat disimpulkan bahwa:

1. Aplikasi simulasi ini dirancang sesuai dengan langkah-langkah yang terdapat pada metode pengembangan multimedia MLDC (Multimedia Life Development Cycle).

2. Selain dapat menggambarkan secara garis besar proses pengolahan sampah menjadi listrik pada skema LK (Listrik Kerakyatan), aplikasi ini juga digunakan untuk mengetahui jumlah listrik yang dihasilkan dari sampah campuran yang dibakar.

3. Aplikasi ini juga dapat digunakan untuk pembuatan laporan hasil pengujian pengolahan sampah menjadi listrik secara harian kepada penanggung-jawab LK.

\section{DAFTAR PUSTAKA}

Ahmadi, M., H.S.Hashim, A.F.Mohamed, N. Moharamnejad. 2013. Toward Соттиnity-based Wate Management: Tehran as a Case Example. Middle-East Journal of Scientific Research. 15(8): 1102 - 1107.

Ezeah, C., J. A. Fazakerley, and C. L. Roberts. 2013. Emerging trends in informal sector recycling in developing and transition countries. Waste Management. 33 (11): 2509-2519.

Horvath, I.S., M.Tabatabaei, K.Karimi, R. Kumar. 2016. Recent Updates on Biogas Production - A Review. Biofuel Research Journal. Vol.10: 394-402.

Legino, S. 2016. Inisiatif Listrik Kerakyatan yang Ramah Lingkungan: Solusi Masalah Sampah Perkotaan Solusi Pasokan Listrik Daerah Terpencil. Jakarta: Penerbit Jurusan Teknik Mesin STT-PLN.

Legino, S. and R. Arianto. 2017. Solving Large Scale Unit Dilemma in Electricity System by Applying Commutative Law, International Conference on Mathematics: Pure, Applied, and Computation.

Luther, A.C. 1994. Authoring Interactive Multimedia. Academy Press.

Pääkkönen, A., H. Tolvanen, and J. Rintala. 2018. Techno-Economic Analysis of A Power To Biogas System Operated Based On Fluctuating Electricity Price. Renewable Energy.

Raharjo, S., T.Matsumoto, T.Ihsan, I. Rahman, L.Gustin. 2015. Community-based Solid Waste Bank Program for Municipal Solid Waste Management Improvement in Indonesia: a Case Study of Padang City. Journal of Material Cycles and Waste Management.

Visvanathan, C. and A. Abeynayaka. 2012. Development and Future Potentials of Anaerobic Membrane Bioreactors (AnMBRs). Membr. Water Treat.. 3, p. $1-23$.

Wang, A.L., T. Damartzizs, S. Diethelm, J.V. Herle, and F.Marechal. 2018. ThermoEconomic Evaluation of Sustainable Biogas Upgrading via Solid -Oxide 
Electrolysis. Energy Power Engineering. 12 (4): 1607.

Wahyuni, T. 2016. Indonesia Penyumbang Sampah Plastik Terbesar ke-dua Dunia. CNNIndonesia, 23 Februari 2016, https://www.cnnindonesia.com/gayahidup/2016022218 2308-277-112685.

Widyastuti, A.Y. 2018. KLHK: Jakarta Produksi 70 Ribu Ton Sampah Setiap Hari. Tempo, 21 Januari 2018, https://bisnis. tempo.co/read/1052480.

Wikandari, R., S.Youngsukkasem, R.Millati, M.J.Taherzadeh. 2014. Performance of Semi-continuous Membrane Bioreactor in Biogas Production from Toxic Feedstock Containing D-Limonene.
Bioresource Technology. 170, p.350355.

Wilson, D.C., C. Velis, and C. Cheeseman. 2006. Role of informua al sector recycling in waste management in developing countries. Habitat International. 30 (4): 797-808.

Yong, Z. ,Y.Dong, X.Zhang, T.Tan. 2015. Anaerobic Co-digestion of Food Waste and Straw for Biogas Production. Renewable Energy. 78, p. 527-530.

https://www.cnnindonesia.com/gayahidup/20160222182308-277112685/indonesia-penyumbang-sampahplastik-terbesar-ke-dua-dunia 